\title{
How news media literacy is taught in Australian classrooms
}

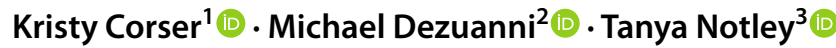

Received: 23 October 2020 / Accepted: 17 May 2021 / Published online: 12 July 2021

(c) The Australian Association for Research in Education, Inc. 2021

\begin{abstract}
News media literacy has come to receive considerable public attention in recent years in the context of anxieties about the impact of misinformation on society. This article outlines research that examines how Australian teachers perceive and value news media literacy and it explores their experiences of teaching news in the classroom. The article presents findings from an online survey of 295 Australian teachers and follow-up semi-structured interviews with 20 teachers. Our analysis finds that although many teachers value students' learning about the news, there are significant challenges and barriers to address if the approach is to become more widely available in Australian classrooms. Teachers lack direction about how news should be taught to young people, the curriculum is already crowded, limiting opportunities to address news, and teachers lack access to relevant professional development. The article provides insights into how to move forward to ensure young people receive adequate education about news in Australia, with the findings holding relevance to other countries facing similar challenges.
\end{abstract}

Keywords News media $\cdot$ Australian teachers $\cdot$ Curriculum $\cdot$ News literacy $\cdot$ Media literacy

\section{Introduction: Teaching news media in Australian classrooms}

News can be defined as "as any accurate information that facilitates decision-making on both personal and social issues, thus enabling people to more effectively engage with society" (Vraga et al., 2020, p. 2). The Internet has profoundly impacted the way young Australians participate in society, including how they engage with news. Digital platforms rival traditional media, such as television, for young people's

Michael Dezuanni

m.dezuanni@qut.edu.au

1 Google Practice Education Transformation Lead - Australia, Datacom, Brisbane, Australia

2 Digital Media Research Centre, Queensland University of Technology, Brisbane, Australia

3 Western Sydney University, Sydney, Australia 
attention when it comes to accessing both information and entertainment. In this context, news is produced and circulated rapidly via an ever-growing number of social media platforms, while social media users encounter news from a range of sources, often while news events are still unfolding. Social media platforms increasingly play a role in determining how young people access and engage with news and are redefining news; changing the way it looks, feels and is experienced (Clark \& Marchi, 2017). In Australia 38\% of children (aged 8-12 years) report receiving news from social media often or sometimes, while $75 \%$ of teens report this (Notley et al., 2020). The pace of collaborative news curation and sharing through social media makes verifying sources and checking claims complicated (Bruns \& Highfield, 2015). In addition, there is evidence that complex and sophisticated methods and strategies are used to circulate disinformation online, which is often presented as news, with the overall concept of 'news' becoming increasingly contested and unstable (Bruns, 2019, p. 11). This has led to a number of flashpoints for claims and counterclaims about 'fake news' at critical moments during elections, natural disasters, acts of terrorism and most recently, during the Coronavirus pandemic.

Researchers, policymakers and educators have argued that media literacy education has the potential to prepare young people so that they are capable o2020f identifying, dismissing and addressing misinformation when they encounter it (for example see Vraga \& Tully, 2019; Jones-Jang et al., 2021; McGrew, ). In addition, some scholars have argued that news media literacy can reduce the impact of racial and ethnic stereotypes evident in news media content (Scharrer \& Ramasubramanian, 2015), which has profound relevance following the 2020 Black Lives Matter demonstrations in the United States and around the world, including in Australia. Some studies show a link between young people being able to engage critically with news and their increased engagement in a range of civic activities (Martens \& Hobbs, 2015; Mihailidis, 2008). News literacy education can also increase young people's interest in news, which in turn can expand their interest in local and world events and their participation in society more broadly (Buckingham, 2000; Mihailidis, 2008; Clark \& Marchi, 2017).

At this critical juncture, it is essential that we understand the efforts already being made in schools to educate young Australians about news media. Very little research has been conducted about how news is integrated into Australian schools, and there has been little exploration of the extent to which teachers feel able and supported to teach students about the news. One insight into the amount of news being taught in schools comes from two nationally representative surveys of young Australians' (8-16 years) news practices conducted in 2017 and 2020. The 2020 findings show that while following the news is important to half of young Australians (49\%) and most young people consume news regularly from multiple sources, only 1 in 5 (20\%) reported having any lessons to help them to 'decide whether news stories are true and can be trusted' and this had not changed since 2017. One in three (34\%) young people had received at least one lesson to help them create their own news stories (Notley et al., 2017, 2020).

To address the gap in knowledge about how news is taught in Australian schools, this article outlines survey findings from 295 Australian teacher respondents. They were asked about their attitudes towards teaching news literacy, their classroom 
practices and the challenges they face in including news education in the classroom. This was followed by interviews with 20 of the survey respondents. The research is timely given that the 2019 Australian Competition and Consumer Commission Digital Platforms Inquiry (ACCC, 2019) emphasises the importance of 'digital media literacy' education in schools and recommends that the terms of reference for the review of the Australian Curriculum scheduled for 2020-2021 include a consideration of the approach to digital media literacy education in Australian schools.

Australia has one of the few international media literacy curriculum policies in the form of Media Arts in the Australian Curriculum (ACARA, 2018), which provides a framework for teaching media production and critical media analysis from pre-school through to Year 10. News media are mentioned several times in the Media Arts curriculum content descriptors and elaborations. In addition, media literacy has a significant presence in the Australian Curriculum, English (ACARA, 2020), which references information and media as core text types for students' consideration. The English curriculum points to news and newspaper examples several times in content elaborations for students in Years 6-10. News is also covered in some State curriculum documents in other, non-direct ways. For instance, for the Victorian Certificate of Education, English, students are required to study 'Issues' and this often results in students focussing on news-based issues and text types. It is encouraging that the news is either directly or indirectly studied in English because the English curriculum is compulsory for most students throughout their schooling, while Media Arts is elective in secondary schools. A complicating factor, though, is that Australian Curriculum content elaborations are illustrative rather than being 'core' or compulsory, and Australia's states and territories are responsible for implementing the curriculum, meaning the national curriculum is implemented in various ways across the country. In addition, different structures and practices exist in primary and secondary schools, and this leads to further variation and complexity in how news might be offered in different kinds of classrooms. It is quite possible, then, for news to be studied in depth in some classrooms and schools and not others, according to teacher, school and State preferences.

It is notable that Australia has a long history of media literacy education. In the late 1940s, William Perkins, an academic at the University of Tasmania, promoted film appreciation as part of the Tasmania English Curriculum, and in the early 1960s he wrote a textbook 'Tasmanian English for Citizens' which included a section on newspapers (Perkins, 1963). In the 1950s, the University of Melbourne's N.H. Rosenthal developed a film and media textbook for schools (Rosenthal, 1953). In 1969, the journal 'English in Australia' included a special issue on 'Mass Media and Television' (Watts, 1969), drawing attention to media literacy as a scholarly concern. Throughout the 1960s and '70s the media teacher's association-first called Australian Teachers of Film Appreciation, and later Australian Teachers of Media (ATOM) - supported a generation of English and Media teachers to support media literacy activities in the classroom, including the study of news. In addition to this, Australian English and Media textbooks produced in the 1970s included sections on 'the press' and newspapers (Dwyer, 1971; Barr, 1977). Finally, starting in the late 1970s, most Australian States' curriculum authorities or Departments of Education published Media curriculum policies and resources, often including a section 
on news media (see for instance: Western Australian Department of Education, 1979, 1982; South Australian Department of Education, 1983; Ministry of Education, Victoria, 1983; NSW Department of Education, 1984; Queensland Education Department, 1985). The findings of our study should be understood against this background of substantial efforts in the past, and present, to support the teaching of media literacy, and news, in Australian classrooms.

\section{Expectations for media literacy education}

News literacy is an important component of digital media literacy and media literacy is necessary to promote appropriate, effective and safe use of media in everyday life. A core media literacy education objective is to foster critical media engagement. This goes beyond the development of technical skills and competences, or personal response to texts, to promote engagement with social, cultural, political and economic perspectives, values and ideas, including a critique of how these are created, circulated, used and consumed via media. A person who is 'critical' from a media literacy perspective typically reflects on their own and others' engagement with media and is curious about how media are made and how they use techniques to communicate and understand the different ways media influence and impact society. This is pertinent to how media literacy is constructed within the English curriculum. Jetnikoff (2007, p. 99), an advocate for media literacy education in English, argues that "media education, which includes media literacy, promotes intellectual engagement, critical analysis and creative application from active users and consumers". Buckingham and Sefton-Green (1994) argued in the 1990s that the introduction of media and popular culture into the English classroom required a shift from a focus on personal response to texts, towards a critical response in which students learn to apply analysis of the construction of meaning of a range of text types. Burn and Durran (2007) point out that media literacy is often located in the English curriculum in schools in Britain and should consist of three key literacy components: the cultural, critical and creative. Given the ever-increasing reach of media across all domains of our lives, then, developing critical media engagement in both English and Media classrooms is more important than ever (Buckingham, 2019; Kellner \& Share, 2019; Mihailidis, 2019).

Researchers argue that it is imperative that teachers, policymakers, scholars and parents are supportive of developing young people's critical thinking skills by encouraging problem solving, through challenging what they see and hear, and by asking key questions about the news media they encounter, wherever they encounter it (Ashley, 2019; Mihailidis, 2012). Fadel and Preston's (2017) research outlines the importance of students' exposure to contemporary news events to support the current core knowledge and concepts in the Australian curriculum. Other research shows, though, that the curriculum needs to be more effective in supporting teacher's news media pedagogy since the development of proficient media education requires that teachers be media literate themselves (Simons et al., 2017). A report by Nettlefold and Williams (2018), based on a survey of 97 teachers in Tasmania, suggests that teachers value media literacy and they agree students' need to develop 
critical thinking skills. However, changes to the current Australian Curriculum may be necessary to advance news media literacy in the classroom (Nettlefold \& Williams, 2018), a finding supported by our research.

Curriculum and pedagogy need to respond to new digital platforms to ensure that the increasing role these platforms have in mediating young people's everyday lives is addressed, including young people's information seeking habits and behaviours (Mihailidis, 2011). Buckingham (2000) recognised the media cultures that shape, and emerge from, young people's news consumption, and the challenge of curriculum conservatism resulting in a disconnect between young people and their education about news media. Ashley (2019) states that, given the rise of misinformation, there is now broad agreement that news media has a place in education, although the form that this should take remains contested and unclear. It is concerning that there is no clear policy about what news media literacy should consist of in the classroom. However, it is perhaps more concerning that research suggests that in the Australian context, news media education remains a relatively marginal activity (Notley et al., 2017; Nettlefold \& Williams, 2018) and there are inconsistencies across educational sectors, including Catholic, Independent and State school sectors (Nettlefold \& Williams, 2018). Appropriate curriculum reform would ensure that all students gain the necessary skills required for successful news consumption and participation in the twenty-first century.

\section{Methodology}

To address the concerns outlined above, we designed our research to better understand teachers' attitudes towards news media literacy, their experiences of teaching it, and the barriers and challenges they face in implementing it in the classroom. The data outlined below report on results from a survey and follow-up semi-structured interviews. A mixed quantitative and qualitative methodological approach allowed us to capture both diverse practices and more nuanced experiences and attitudes.

\section{Online survey}

An online survey was conducted between November 2019 and February 2020. Qualtrics Core XM Survey Tool was used to develop the survey which was promoted via email to teachers who were subscribed to email lists managed by the Australian Broadcasting Corporation Education team and the Museum of Australian Democracy (MoAD). The survey was also promoted on social media by the researchers and by ABC Education and MoAD. A total of 323 teachers from around Australia began the survey, however, 28 respondents were excluded because they only completed the first 8 questions, which asked for general demographic information. Two hundred and ninety-five respondents answered questions 9 and 10, and between 228 and 292 respondents completed the remainder of the questions. It is a study limitation that teachers who have subscribed to receive information from MoAD and ABC Education may be more likely to have an interest in English and Humanities education, 
and perhaps media literacy, as $\mathrm{ABC}$ Education promotes media literacy resources on its website. More English teachers completed the survey than any other subject area (24\%), and the majority of respondents were secondary school teachers (80\%). As Table 1 illustrates, the majority of teachers come from three States, perhaps reflecting that teachers in those States are over-represented on MoAD and ABC Education databases. In addition, a higher percentage of teachers answering the survey come from independent schools (23\%), than are represented in independent schools across the country $(11 \%)$. While the survey is not representative of all Australian teachers, however, there was significant diversity among the respondents in terms of geography, subject areas, socioeconomic status of their school and their years of teaching experience. The following table (Table 1) presents the breakdown of the responses from 295 respondents.

The questions for the survey were designed with the target participants in mind, including Australian teachers across the different sectors of schooling including government, independent and Catholic, secondary and primary school, and any area of subject specialisation. The survey consisted of 25 questions including multiple choice, open responses and Likert scale questions. Adaptations were made to the questions and design after a select number of teachers trialled the survey. The survey took an average of 10 minutes for teachers to complete, with the option to participate in a follow-up interview. Indicative questions included were as follows:

How much importance does your school place on teaching about news in the classroom?-A lot; Some; A little; Not at all; Unsure.

Have you created and/or taught a specific unit of work to teach students about the news?

What are the key barriers that prevent you from teaching about news?-The timetable and how it is structured; Lack of time for planning; The challenge of discussing sensitive topics in the classroom; Concerns regarding the age appropriateness of news; Poor quality Internet access, or access to technology for getting resources; Lack of knowledge/training.

\section{Semi-structured interviews}

After completing the survey, all respondents were invited for a follow-up interview, with 86 making themselves available. Of these, 20 participants were selected to reflect diversity in terms of years of teaching experience, school location and area of specialisation. The interviews were carried out online using video conference software and were video and/or audio recorded, with each approximately $30 \mathrm{~min}$ in length. The interviews were used primarily to ask the participants to extend on their responses to some of the survey questions and to expand on their personal experience of teaching news media in the classroom. The qualitative data generated from the interviews included notes taken during the interviews, followed up with in-depth note taking and transcription of key quotes after each interview. Some key themes were manually identified based on the notes and quotations. Analysis focussed on the themes, categories and issues that emerged relating to teaching and learning 
Table 1 Participant information

Geographical location (States and Territories)

NSW

$38 \%$

QLD

WA

$17 \%$

VIC

SA

Years of teaching experience

$1-5$ years

21-25 years

Gender

Female

Male

Other/Prefer not to say

Socioeconomic status of the community they teach in

Upper

Middle

Low

Unsure

Geographical location

Major City

Inner Regional

Outer Regional

Remote/Very Remote

Sector

State/Government

Catholic

Independent

Year level/s taught

Primary (P/K-6)

Lower Secondary (7-9)

Upper Secondary (10-12)

Subject Area Specialisation

Generalist Primary Teacher

English

Mathematics

Science

Humanities and Social Science 
Table 2 How important is it for students to learn the following?

\begin{tabular}{llllcc}
\hline Skill & $\begin{array}{l}\text { Extremely } \\
\text { important }\end{array}$ & Very important & $\begin{array}{l}\text { Mod- } \\
\text { erately } \\
\text { important }\end{array}$ & $\begin{array}{l}\text { Slightly } \\
\text { impor- } \\
\text { tant }\end{array}$ & $\begin{array}{l}\text { Not at all } \\
\text { important }\end{array}$ \\
\hline Skills for critically reading news & $79 \%$ & $17 \%$ & $3 \%$ & $1 \%$ & $0 \%$ \\
News fact checking and verification & $66 \%$ & $28 \%$ & $5 \%$ & $1 \%$ & $0 \%$ \\
$\begin{array}{l}\text { Using and comparing multiple news } \\
\quad \text { sources }\end{array}$ & $58 \%$ & $34 \%$ & $6 \%$ & $2 \%$ & $0 \%$ \\
$\begin{array}{l}\text { Students making/producing news } \\
\text { tude }\end{array}$ & $18 \%$ & $34 \%$ & $36 \%$ & $10 \%$ & $2 \%$ \\
\hline
\end{tabular}

about news media in the classroom. Thematic analysis also allowed meaning, discourse and patterns to be identified (Braun \& Clarke, 2006).

\section{Survey findings}

This section discusses the key findings that emerged from the survey, including our analysis of how teachers understand and prioritise the teaching of news in the classroom.

\section{Teaching news matters}

Almost all respondents (96\%) believed it was very/extremely important for students to learn to critically read the news and $94 \%$ of teachers believed it was very/ extremely important for students to learn news fact checking and verification skills (see Table 2). The ability to check and verify news was also considered very/ extremely important for nearly all respondents (94\%); and the ability to use and compare multiple news sources was seen to be very/extremely important (93\%). Interestingly, teachers were divided over their opinion about the need for students to produce their own news, with nearly half (46\%) rating this moderately or slightly important. Critical news literacy knowledge skills are therefore seen to be more important to the survey respondents than journalistic skills. Over $90 \%$ of respondents believed it was very/extremely important for students to learn about bias in the news (see Table 3). These findings suggest that teachers place a high degree of importance on teaching students about the news, especially those aspects that are about media manipulation (including issues of bias) and disinformation (also referred to as 'fake news'). Teachers also indicated a very high level of support for teaching about news as it relates to the individual wellbeing (emotional impact), and to citizenship. While the significance placed on teaching students about specific news distribution channels and companies (mainstream news and social media) was slightly lower than for the other categories, there was still a high level of support for teaching these aspects. Over three quarters of respondents $(77 \%)$ said they often or sometimes taught their students about news media, demonstrating many of the respondents made the effort to include a focus on news media in their classrooms. 
Table 3 How important is it for students to be taught the following?

\begin{tabular}{lccccc}
\hline Skill & $\begin{array}{l}\text { Extremely } \\
\text { important }\end{array}$ & Very important & $\begin{array}{l}\text { Mod- } \\
\text { erately } \\
\text { important }\end{array}$ & $\begin{array}{l}\text { Slightly } \\
\text { impor- } \\
\text { tant }\end{array}$ & $\begin{array}{l}\text { Not at all } \\
\text { important }\end{array}$ \\
\hline $\begin{array}{l}\text { Stories that feature on mainstream } \\
\text { news }\end{array}$ & $21 \%$ & $41 \%$ & $30 \%$ & $6 \%$ & $1 \%$ \\
$\begin{array}{l}\text { Issues relating to fake news } \\
\text { Social media and news }\end{array}$ & $44 \%$ & $37 \%$ & $14 \%$ & $3 \%$ & $2 \%$ \\
$\begin{array}{l}\text { Bias in the news } \\
\text { Citizenship and the news }\end{array}$ & $30 \%$ & $39 \%$ & $23 \%$ & $7 \%$ & $1 \%$ \\
\hline
\end{tabular}

Table 4 Do you feel confident in teaching about news?

\begin{tabular}{lc}
\hline Response & Percentage \\
\hline Extremely confident & 24 \\
Quite confident & 44 \\
Moderately confident & 24 \\
Somewhat confident & 7 \\
Not confident & 1 \\
\hline
\end{tabular}

\section{Most teachers feel they are able to teach news, but there are many barriers}

Despite around a quarter (24\%) of the respondents stating that they felt extremely confident teaching about news, and an additional $44 \%$ stating that they were quite confident teaching about news (Table 4), teachers faced many barriers that prevent them from doing this. The major barriers cited were timetable constraints and curriculum structures $(57 \%)$ and a lack of time for planning (45\%). It is unsurprising that timetabling, curriculum structures or the 'crowded curriculum' were seen to be significant issues for teachers, given that it is widely accepted that Australian teachers believe they have too much content to cover, as identified in various reviews of the Australian Curriculum (Department of Education, 2014). As discussed, being 'time poor' is also well established as a significant challenge for teachers who are unable to be more creative with learning experience development.

Around one quarter of respondents $(27 \%)$ said they felt very well supported by their school to teach about news, while an additional $38 \%$ felt moderately well supported (see Table 5). Despite this, more than one-third (34\%) felt only somewhat supported, or not supported at all, indicating improvements could be made by schools to support teachers to include news media literacy in their classrooms. Only $18 \%$ of the teachers surveyed indicated they had access to professional development opportunities for assistance with teaching about the news. Teachers typically identified professional development as access to specially designed workshops, seminars and information sessions. This low percentage suggests few of these dedicated opportunities exist, and if they do, they are not widely known about, available or accessed by teachers. Given that teachers in Australia are required to access 
Table 5 Do you feel supported news? by your school in teaching about

\begin{tabular}{ll}
\hline Response & Percentage \\
\hline Very supported & 27 \\
Moderately supported & 38 \\
Somewhat supported & 27 \\
Not at all supported & 8 \\
\hline
\end{tabular}

Table 6 Does the Australian Curriculum support you to teach students about news media?

\begin{tabular}{ll}
\hline Response & Percentage \\
\hline Yes, completely & 10 \\
Yes, somewhat & 53 \\
No & 15 \\
Not sure & 22 \\
\hline
\end{tabular}

professional development to retain their teacher registration, there is an opportunity for a greater number of dedicated and high-profile professional development workshops about news literacy to be offered to teachers.

\section{Changes to the Australian Curriculum may be necessary}

The Australian Curriculum needs to be clearer in how it directs teachers to develop student learning experiences across the curriculum given that $15 \%$ of teacher respondents said that they were not well supported by the Australian Curriculum (ACARA) to teach about news. An additional 22\% said they were unsure if they were supported by the curriculum (see Table 6). While it is encouraging that a significant number of the teachers turn to the ACARA documents to support their teaching about news, it is concerning that a significant number did not believe or were unsure if the Australian Curriculum supports them to teach about news. Only a small number of the respondents said the Australian Curriculum places no importance on teaching news (3\%), but an additional 33\% said the documents place only 'a little' importance on teaching about news. Only 7\% of the respondents believed their school places 'a lot' of importance on teaching about news, while $39 \%$ said their school places 'some' importance on this. When contrasted with earlier results about 'support' for teaching the news, this leads to a somewhat surprising finding that while teachers believed they are supported to teach news, a significant number simultaneously believed ACARA does not place importance on teaching about the news. In other words, a greater number of teachers suggested the curriculum allows them to teach about the news, than believed the curriculum encourages them to teach about the news. This may simply reflect that the Australian Curriculum provides teachers with choice about the specific content or topics they teach, as opposed to being prescriptive. However, this lack of specificity reduces the likelihood that all students will receive at least some news media literacy education while at school. 
While our survey cannot be seen to represent all teachers, we believe the 295 responses make this the largest survey to examine teaching and news media in Australia and our analysis shows that the respondents are diverse in terms of geography, subject areas and teaching experience. Our survey findings show that the respondents believed that teaching students about news is very important and many teachers are regularly doing so. Other studies corroborate the finding that Australian teachers value students developing news literacy skills (e.g. Korona, 2020; Nettlefold \& Williams, 2018). However, despite almost all teachers wanting to teach students about news, one-third of teachers are not very confident about doing so. Teachers' lack of confidence in teaching news is not a new finding as other research also confirms this trend, in particular when this involves teaching topics of a sensitive nature (37\% of teachers in our survey indicated this was a challenge) (Bickmore \& Parker, 2014; Byford et al., 2009). Our findings also demonstrate there are multiple barriers that stand in the way of news media literacy education and these will need to be addressed by relevant stakeholders.

\section{Conversations with teachers}

To gain further detailed information from the participants, teachers were invited to have an in-depth, 30-minute phone or online conversation about expectations and experiences of teaching news literacy in the classroom. A thematic analysis was conducted of the interviews which revealed why the teachers thought it was important to teach young people about news. Teachers also discussed curriculum connections and policy associated with teaching news media in the classroom and challenges, difficulties and barriers they faced that made teaching about news difficult or impossible. To retain anonymity, the teachers are referred to as Teachers 1-20 in the following discussion. ${ }^{1}$

\section{Why is it important to teach about the news?}

The teacher interviewees showed support for teaching news media to their students, revealing their belief in the importance of teaching critical news literacy skills. For instance, a primary school teacher from Queensland argued:

It's a really important part, you hear about fake news, all of those things... for kids to be able to have that basis and understanding that things are not always what they may seem, being able to question, being critical of whatever they are getting in their media. (Teacher 12, Prep to Year 12 Queensland Information Literacy teacher)

Other teachers from Western Australia, New South Wales and Queensland held similar views, identifying the importance of young people developing critical literacy

\footnotetext{
1 See appendix in Dezuanni et al., (2020).
} 
skills, including being aware of bias in the news, and the importance of checking references and sources of information. Teachers also stressed that they want students to be accessing the news, particularly topics that are relevant to them, but importantly they want them to understand and recognise reliable sources of information and in particular they want them to be critical when accessing the news through their social media feeds. Teachers discussed that they want their students to understand how social media algorithms work as well as celebrity endorsements. Several teachers explained that they want their students to know when they are being advertised to because if they are unable to do this, they are at risk of being exploited.

\section{Curriculum connections and policy}

Teachers provided responses on curriculum and policy in the interviews, particularly about the Australian Curriculum and acknowledged the presence of news media literacy content with varying degrees of satisfaction. Constraints of the curriculum were of concern and need to be addressed to ensure teachers feel supported by the national policy. Teachers discussed how they felt they were required to teach particular topics and the lack of support about how to teach some content, in addition to their concerns regarding the amount of content they are required to cover. One teacher explained:

Our curriculum is so packed, it's probably a complaint of lots of teachers, there is just so much to get them through and I don't think media studies is compulsory, maybe that needs to be considered. I like doing it in the context of English, it really fits when you're looking at rhetorical devices, but I'm always conscious of the constraints of the curriculum. (Teacher 18, Western Australia Primary English Teacher)

A primary school teacher discussed the need to be able to teach current, relevant events and topics to students, however, she highlighted her perception that there is a lack of flexibility in the Australian Curriculum and that this restricts her pedagogy. In addition, another teacher discussed how she thought the Curriculum lacked flexibility and that this may hamper students' tendencies to question the world around them. Overall, the teachers recognised that the Australian Curriculum allowed aspects of news media literacy such as critical thinking, however, they suggested more specific news literacy skills might be lacking, or overlooked by teachers. Other teachers drew attention to the need to implement the curriculum appropriately in lesson planning to ensure it remains relevant. For instance, a secondary teacher from New South Wales said that teachers are required to interpret and supplement the curriculum to ensure it remains relevant to contemporary media, suggesting appropriate lesson plans and support materials would be beneficial. In addition, teachers were particularly supportive of the Media Arts Curriculum, which they said provides opportunities to teach about news, with one stating "the Media Arts curriculum easily allows for the teaching of news" (Queensland Senior Secondary Arts Teacher-qualitative survey response). 
Some teachers discussed receiving adequate support from their school to teach news media to their students, in particular if it was in line with the broader policies and priorities of the school. However, one teacher from a rural area felt less well supported by their school: "Being at a small school I am really on my own in developing resources. Accessing PD [professional development] is difficult for teachers in rural areas" (New South Wales Secondary English Teacher-qualitative survey response).

In addition to seeking support from school, external professional development was also discussed by some teachers. Teachers regularly accessed online material and networks such as ABC Education and Australian Teachers of Media resources. Teachers discussed the importance and satisfaction of collaboration and collegial discussions among staff members for accessing and developing new and relevant resources for exploring media literacy. Local news outlets were also seen to be a source of support, with a Queensland secondary teacher stating, "I have had wonderful support from local newspapers" (Queensland Junior Secondary Technologies Teacher-qualitative survey response). One teacher mentioned the long running ABC program Behind the News, but believed another version for younger students would be appropriate: " $\mathrm{BtN}$ is a great resource but not always appropriate for Year 3 which is what I'm teaching. Another version or edit for younger students would be great" (New South Wales Primary HASS/English Teacher-qualitative survey response).

\section{Challenges, difficulties and barriers}

Challenges, difficulties and barriers to teaching news media literacy were discussed by the teachers during the interviews including lack of time, an overcrowded curriculum and restricted access to resources, including hardware and Internet access. One of the most consistent responses was finding the time in the curriculum to teach students about the news in the classroom: "Probably the only reason we don't spend more time on teaching them about the news is a very crowded curriculum" (Victorian Secondary School English Teacher-qualitative survey response). Another teacher agreed, suggesting the demands of the existing curriculum left little room for teaching about news, arguing that the "content level and quantity is so demanding that the discussion and debate necessary for addressing the news in a classroom environment is not possible" (Queensland Junior Secondary Gifted Education Specialist Teacher-qualitative survey response). In addition to lack of time and an overcrowded curriculum, other teachers discussed their concerns about students not being able to access certain online content while at school such as social networking sites. One teacher from Western Australia explained:

A lot of the social networking sites are blocked at school so the kids can't access Facebook, Twitter and Instagram because they are all blocked, so trying to get them to actually undertake relevant research and exploration of these things can actually be really tricky and some of our kids also don't have social media. (Teacher 19, Western Australian Secondary English/Arts Teacher) 
Internet filtering systems in schools often result in blocked websites which has long been a concern for teachers who are attempting to teach relevant news media skills to their students but are faced with limited or no access (Notley, 2008). Several teachers also mentioned the technological challenges involved with teaching about news. One teacher from a low socioeconomic community explained that access is via one computer lab only and many students do not have computers at home due to their low socioeconomic household status. This highlights the relationships between digital exclusion and inequality and the need to carefully consider supporting news media literacy in low socioeconomic areas with adequate and appropriate resources.

\section{Discussion and conclusion}

News reflects and plays a role in establishing public agendas while misinformation presented as news can contribute to devastating health, social and political consequences. Therefore, news media literacy is critical for citizens. News literacy can play a role in helping citizens to make more conscious and informed decisions about their news practices and sources and encourage greater news engagement (Maksl et al., 2017). News literacy education can also help citizens to identify misinformation (McGrew, 2020) and they can increase the ways that individuals engage with democracy (Clark \& Marchi, 2017; Mihailidis \& Thevenin, 2013), while supporting students to recognise racial and ethnic minority underrepresentation as well as the use of racial and ethnic stereotypes (Scharrer \& Ramasubramanian, 2015). Despite these benefits, news literacy education in schools is addressed by Australian teachers less often than we would like. However, political and public anxieties about the impact of misinformation have now put news media literacy firmly on the public agenda. While this is positive, it is worth noting that news media literacy encompasses far more than a set of technical, digital skills that aim to identify misinformation-skills that will likely be made redundant as technologies continue to develop. Rather, news media literacy should promote civic reasoning and a lifelong engagement with social, cultural, political and economic perspectives, values and ideas, including knowledge about how to critique how news is created, circulated, used and consumed and the ability to think through issues of power, ownership and control.

Our research finds that Australian teachers do believe that teaching news is very important and should be prioritised. However, teachers are limited or held back from teaching about news because of perceived curriculum restrictions and a lack of time to prepare lessons, a lack of clarity as to how and when to use news in the curriculum. Australian education policymakers need to address the barriers that prevent teachers from teaching students about news as a priority if they want to ensure that all students receive news media literacy education. At the same time, a range of other news media, media literacy and youth-focussed organisations can play a role in addressing these barriers by creating learning materials and teacher training opportunities that align with the Australian Curriculum and relevant State Curriculum documents while ensuring this education is timely and future orientated, supporting students to assess news regardless of where and how it is delivered. Researchers can 
support media literacy by developing an evidence base to indicate what effective news media literacy education materials should include as well as the most appropriate pedagogical approaches.

If news media literacy seeks to reduce the impact of misinformation and teachers are given the responsibility for achieving this, learning materials must be evidence based. At the same time, given the significant role of news in our democracy, society and economy, it is also vital that news media literacy objectives do not only focus on preventing misinformation. As we outlined at the beginning of this paper, there are a range of ways in which the news media are changing as a result of the ubiquity of the Internet and the rise of digital platforms. Therefore, educators must find ways to develop new understandings to teach about news that reflect their students' everyday news interactions. At this time of great change in the news media landscape, students need to have the knowledge and capacity to think about and deal with future news media environments, whatever form they take, while students should also be encouraged to be involved in determining what this future looks like through their active engagement in policy, regulatory and public debates.

\section{Author contributions Not applicable.}

Funding The research this paper reports on part of the second phase of the Advancing the Media Literacy of Young Australians project. This phase of the project received funding from Google Australia and the Museum of Australian Democracy. For more information see https://www.westernsydney.edu.au/ medialiteracy/.

Data availability Not applicable.

Code availability Not applicable.

\section{Declarations}

Conflict of interest The authors declare that they have no conflict of interest.

\section{References}

Ashley, S. (2019). News literacy and democracy. Routledge.

Australian Curriculum, Assessment and Reporting Authority (ACARA). (2018). The Australian Curriculum: Media Arts. Sydney, NSW, Australia: Australian Curriculum, Assessment and Reporting Authority. Accessed May 15, 2020. https://wwvulum.edu.au/f-10-curriculum/the-arts/mediaarts/

Australian Curriculum, Assessment and Reporting Authority (ACARA). (2020). The Australian Curriculum: English. Sydney, NSW, Australia: Australian Curriculum, Assessment and Reporting Authority. Accessed February 22, 2021. https://www.australiancurriculum.edu.au/f-10-curriculum/english/

ACCC. (2019). Digital Platforms Inquiry. Accessed May 15, 2020. https://www.accc.gov.au/focus-areas/ inquiries-ongoing/digital-platforms-inquiry

Barr, T. (1977). Reflections of reality: The media in Australia. Rigby.

Bickmore, K., \& Parker, C. (2014). Constructive conflict talk in classrooms: Divergent approaches to addressing divergent perspectives. Theory \& Research in Social Education, 42(3), 291-335. https:// doi.org/10.1080/00933104.2014.901199

Bruns, A. (2019). Are filter bubbles real? Polity Press. 
Braun, V., \& Clarke, V. (2006). Using thematic analysis in psychology. Qualitative Research in Psychology, 3(2), 77-101.

Bruns, A., \& Highfield, T. (2015). From news blogs to news on Twitter: Gatewatching and collaborative news curation. In S. Coleman \& D. Freelon (Eds.), Handbook of digital politics (pp. 325-339). https://doi.org/10.4337/9781782548768.00029

Burn, A., \& Durran, J. (2007). Media literacy in schools: Practice. Sage.

Byford, J., Lennon, S., \& Russell, W. (2009). Teaching controversial issues in the social studies: A research study of high school teachers. The Clearing House: A Journal of Educational Strategies, Issues and Ideas, 82(4), 165-170. https://doi.org/10.3200/TCHS.82.4.165-170

Buckingham, D. (2000). The making of citizens young people, news, and politics (1st ed.). Routledge.

Buckingham, D. (2019). The media education manifesto. Polity Press.

Buckingham, D., \& Sefton-Green, J. (1994). Cultural studies goes to school: Reading and teaching popular media. Taylor and Francis.

Clark, L., \& Marchi, R. (2017). Young people and the future of news: Social media and the rise of connective journalism. Cambridge University Press. https://doi.org/10.1017/9781108116015

Department of Education. (2014). Review of the Australian Curriculum: Initial Australian Government Response. Accessed May 15, 2020. https://docs.education.gov.au/system/files/doc/other/initial_austr alian_government_response_final_0.pdf

Dezuanni, M., Notley, T., \& Corser, K. (2020). News and Australian teachers: How news is taught in the classroom. Brisbane: Queensland University of Technology and Western Sydney University.

Dwyer, B. (1971). Mastering the media: A guide to the discriminating use of the mass media. Reed Books.

Fadel, H., \& Preston, L. (2017). Student interest in current news events: Perspectives of humanities teachers from contrasting schools. Social Educator, 35(2), 4-15.

Jetnikoff, A. (2007). Square-eyed kids are not one eyed: Media education in Australia. Screen Education, 48(1), 98-108.

Jones-Jang, S. M., Mortensen, T., \& Liu, J. (2021). Does media literacy help identification of fake news? Information literacy helps, but other literacies don't. American Behavioral Scientist, 65(2), 371388. https://doi.org/10.1177/0002764219869406

Kellner, D., \& Share, J. (2019). The critical media literacy guide: Engaging media and transforming education. Brill/Sense.

Korona, M. (2020). Evaluating online information: Attitudes and practices of secondary English Language Arts teachers. Journal of Media Literacy Education, 12(1), 42-56. https://doi.org/10.23860/ JMLE-2020-12-1-4

Maksl, A., Craft, S., Ashley, S., \& Miller, D. (2017). The usefulness of a news media literacy measure in evaluating a news literacy curriculum. Journalism \& Mass Communication Educator, 72(2), 228241. https://doi.org/10.1177/1077695816651970

Martens, H., \& Hobbs, R. (2015). How media literacy supports civic engagement in a digital age. Atlantic Journal of Communication, 23(2), 120-137.

McGrew, S. (2020). Learning to evaluate: An intervention in civic online reasoning. Computers \& Education. https://doi.org/10.1016/j.compedu.2019.103711

Ministry of Education, Victoria. (1983). The Media Education Statement. Schools Division, Victoria.

Mihailidis, P. (2008). Beyond Cynicism: How Media Literacy Can Make Students More Engaged Citizens. University of Maryland Dissertation. University of Maryland, College Park, Maryland.

Mihailidis, P. (2011). (Re)Mix, (Re)Purpose, (Re)Learn: Using participatory tools for media literacy learning outcomes in the classroom. Action in Teacher Education, 33(2), 172-183. https://doi.org/ 10.1080/01626620.2011.569421

Mihailidis, P. (2012). News literacy: Global perspectives for the newsroom and the classroom. Peter Lang.

Mihailidis, P. (2019). Civic media literacies: Reimagining human connection in the age of digital abundance. Routledge.

Mihailidis, P., \& Thevenin, B. (2013). Media literacy as a core competency for engaged citizenship in participatory democracy. American Behavioral Scientist, 57, 1611-1622. https://doi.org/10.1177/ 0002764213489015

Nettlefold, J., \& Williams, K. (2018). Insight Five: A snapshot of Media Literacy in Australian Schools. Institute for the Study of Social Change. (Research Report). University of Tasmania. https://www. utas.edu.au/social-change/publications/insights/insight-five-media-literacy-in-australian-schools 
New South Wales Department of Education. (1984). All about mass media education K-12. Directorate of Studies.

Notley, T. (2008). Online network use in schools: social and educational opportunities. Youth Studies Australia, 27(3), 20-27.

Notley, T., Dezuanni, M., Zhong, H. F., \& Howden, S. (2017) News and Australian Children: How Young People Access, Perceive, and are Affected by News Media. Research Report. Western Sydney University and Queensland University of Technology.

Notley, T., Dezuanni, M., Zhong, H. F., \& Chambers, S. (2020) News and Young Australians in 2020: How Young People Access, Perceive, and are Affected by News Media. Research Report. Western Sydney University and Queensland University of Technology.

Perkins, W. H. (1963). Screen education in Tasmania. Screen Education, 20, 9-18.

Queensland Education Department. (1985). Looking at the media. Queensland Education Department.

Rosenthal, N. (1953). Film in our lives. F.W. Cheshire.

Scharrer, E., \& Ramasubramanian, S. (2015). Intervening in the media's influence on stereotypes of race and ethnicity: The role of media literacy education. Journal of Social Issues, 71, 171-185.

Simons, M., Meeus, W., \& T'Sas, J. (2017). Measuring media literacy for media education: Development of a Questionnaire for Teachers' Competencies. Journal of Media Literacy Education, 9(1), 99-115. https://doi.org/10.23860/JMLE-2017-9-1-7

South Australian Department of Education. (1983). R-7 Media Lab. Education Department of South Australia.

Vraga, E., \& Tully, M. (2019). News literacy, social media behaviours, and skepticism toward information on social media. Information, Communication \& Society, 24(2), 150-166.

Vraga, E. K., Tully, M., Maksl, A., Craft, S., \& Ashley, S. (2020). Theorizing news literacy behaviors. Communication Theory, 31(1), 1-21.

Watts, F. (1969). Mass media and the teaching of English. English in Australia, 9, 27-36.

Western Australian Department of Education. (1979). Primary media studies teachers' resource book. Education Department of Western Australia.

Western Australian Department of Education. (1982). Media conventions: A teachers' resource book for secondary media studies. Education Department of Western Australia.

Publisher's Note Springer Nature remains neutral with regard to jurisdictional claims in published maps and institutional affiliations.

Kristy Corser recently graduated with a Ph.D. from Queensland University of Technology's Faculty of Education. Her research interests are in education policy, cloud computing and classroom teaching and learning. She has a background as a primary school educator and currently works in the educational technology industry.

Michael Dezuanni is the Program Leader for Digital Inclusion and Participation for the Digital Media Research Centre at Queensland University of Technology. He undertakes research about digital media, literacies and learning in home, school and community contexts.

Tanya Notley is a Senior Lecturer in Digital Media in the School of Humanities and Communication Arts and a member of the Institute for Culture and Society (ICS) at Western Sydney University. Her research examines the relationship between communication, technology and social change. 